\title{
Expression and effect of NAMPT (visfatin) on progesterone secretion in hen granulosa cells
}

\author{
Mélodie Diot ${ }^{1,2,3,4}$, Maxime Reverchon ${ }^{1,2,3,4}$, Christelle Ramé1,2,3,4, Yannick Baumard ${ }^{5}$ \\ and Joëlle Dupont ${ }^{1,2,3,4,+}$ \\ ${ }^{1}$ INRA, UMR85 Physiologie de la Reproduction et des Comportements, F-37380 Nouzilly, France, \\ ${ }^{2}$ CNRS, UMR7247, F-37380 Nouzilly, France, ${ }^{3}$ Université François Rabelais de Tours, F-37000 Tours, France, \\ ${ }^{4}$ IFCE, F-37380 Nouzilly, France and ${ }^{5}$ INRA, UE 1295, Unité Expérimentale Pôle d'Expérimentation \\ Avicole de Tours, F-37380 Nouzilly, France \\ Correspondence should be addressed to J Dupont; Email: jdupont@tours.inra.fr
}

${ }^{\dagger} \mathrm{J}$ Dupont is now at Unité de Physiologie de la Reproduction et des Comportements, Institut National de la Recherche Agronomique, 37380 Nouzilly, France

\begin{abstract}
In mammals, nicotinamide phosphoribosyltransferase (NAMPT) is an adipokine produced by adipose tissue that is found in intracellular and extracellular compartments. The intracellular form of NAMPT is a nicotinamide phosphoribosyltransferase, whereas the extracellular form is considered an adipokine. In humans, NAMPT regulates energy metabolism and reproductive functions, such as ovarian steroidogenesis. To date, no study has investigated the role of NAMPT in hen ovaries. We investigated whether NAMPT is present in hen ovarian follicles and its role in granulosa cells. Using RT-PCR, western blotting and immunocytochemistry, we detected mRNA transcripts and proteins related to NAMPT in theca and granulosa cells from pre-ovulatory follicles. Using RT-PCR, we demonstrated that mRNA NAMPT levels were higher in granulosa cells than they were in theca cells and that during follicle development, theca cell levels decreased, whereas levels remained unchanged in granulosa cells. NAMPT protein quantities were significantly higher in theca cells than they were in granulosa cells, but they were unchanged during follicular development. Plasma NAMPT levels, as determined by ELISA and immunoblotting, were significantly lower in adult hens than they were in juveniles. In vitro, treatment with human recombinant NAMPT (100 ng/ml, $48 \mathrm{~h}$ ) halved basal and IGF1-induced progesterone secretion, and this was associated with a reduction in STAR and HSD3B protein levels and MAPK3/1 phosphorylation levels in granulosa cells. These effects were abolished by the addition of FK866, a specific inhibitor of NAMPT enzymatic activity. Moreover, NAMPT had no effect on granulosa cell proliferation. In conclusion, NAMPT is present in hen ovarian cells and inhibits progesterone production in granulosa cells.

Reproduction (2015) 150 53-63
\end{abstract}

\section{Introduction}

Nicotinamide phosphorybosyltransferase (NAMPT), also known as a pre-B cell colony-enhancing factor (PBEF), is a $52 \mathrm{kDa}$ mammalian protein that is constitutively synthesised by adipose tissue and many other tissues, including reproductive tissue (Reverchon et al. 2014). NAMPT has been shown to have several intra- and extra-cellular functions, and two isoforms, intracellular and extracellular, have been reported. Intracellular NAMPT plays a critical role in maintaining the activity of nicotinamide adenine dinucleotide (NAD)-dependent enzymes (Revollo et al. 2004). It contributes to the biosynthesis of NAD by acting to convert nicotinamide into nicotinamide mononucleotide $(\mathrm{NMN})$, and it represents the limiting factor for this enzyme reaction (Rongvaux et al. 2002). Intracellular NAMPT activity is inhibited by a pharmacological competitive inhibitor,
FK866, which binds to the active site formed by the dimer (Khan et al. 2006). This means that FK866 can be used to assess the physiological function of NAMPT in cells. Extracellular NAMPT is secreted by various cell types (Revollo et al. 2007a), and its biological role is still not entirely understood. Although the findings remain controversial, several studies have indicated that NAMPT has glucose-lowering and insulin-mimicking or insulin-sensitising effects. No NAMPT receptor has yet been identified, and the molecular mechanism by which NAMPT acts remains unknown. Several researchers, including Revollo and Moschen (Revollo et al. 2007a,b), failed to detect NAMPT binding to insulin receptors (INSRs), although other studies have shown that INSRs play an important role in the actions of NAMPT in peripheral blood mononuclear cells (Dahl et al. 2007) and in human osteoblasts (Xie et al. 2007). 
In mammals, there is some evidence to suggest that NAMPT is directly involved in regulating reproductive functions. NAMPT is present in human ovarian follicles and increases insulin-like growth factor 1 (IGF1)induced steroidogenesis in primary human granulosa cells (Reverchon et al. 2013a). Furthermore, in women who are undergoing controlled ovarian stimulation, there is a correlation between the concentration of NAMPT in the follicular fluids and the number of oocytes retrieved (Shen et al. 2010). In rats, the administration of NAMPT during superovulation has been shown to play an important role in the regulation of oocyte quality, and it can improve oocyte quality and fertility in aged female mice (Choi et al. 2012). NAMPT is expressed in the testes of male rats, more specifically in Leydig cells, spermatocytes and sperm (Gurusubramanian \& Roy 2014). In cultured Leydig cells, NAMPT has been shown to increase testosterone production (Hameed et al. 2012). In humans, NAMPT levels are significantly higher in seminal plasma than in serum, which suggests that testicular cells produce NAMPT (Thomas et al. 2013).

The full-length cDNA of the NAMPT gene has been cloned and sequenced in chickens ( $\mathrm{Li}$ et al. 2012). Chicken NAMPT has high amino acid sequence identity with human and rat NAMPT (94\%) (Li et al. 2012). It has been shown to be expressed primarily in skeletal muscle rather than in visceral adipose tissue, and it was therefore postulated that NAMPT might be a myokine rather than a cytokine (Krzysik-Walker et al. 2008). In chickens, NAMPT gene expression is sex- and tissue-dependent. There is more NAMPT mRNA in the adipose tissue of female chickens than in that of male chickens (Ons et al. 2010). In chicken reproductive tissue, NAMPT is expressed at the gonadotrope axis level, but most research has looked at NAMPT in the testes, and it has been suggested that NAMPT may play an important role in testicular steroidogenesis and spermatogenesis (Ocón-Grove et al. 2010). However, to the best of our knowledge, there have been no reports of NAMPT in hen ovaries, and the present study is the first to elucidate the role of NAMPT in hen granulosa cells in vitro. We also investigated the potential modulation of signalling pathways by NAMPT in these cells.

\section{Materials and methods}

\section{Ethics}

All procedures were approved by the Loire Valley Animal Experimentation Ethics Committee (CEEA VdL, protocol registered as 01607.02) and were carried out in accordance with the guidelines of the French Council for Animal Care.

\footnotetext{
Animals

Fifty-two-week-old laying breed hens ( $n=50$, ISA Brown, egg layer type, Institut de Selection Animale, Saint Brieuc, France)

were housed individually in laying batteries with free access to feed and water and a $15 \mathrm{~h}$ light: 9 h darkness cycle. Individual lay patterns were monitored daily. Hens were killed by exsanguination following electronarcosis (Sanofi-santé, Libourne, France) between 10 and $12 \mathrm{~h}$ before the next oviposition, and the ovaries were immediately removed and placed in ice-cold sterile $1 \% \mathrm{NaCl}$ saline solution for immediate use. Granulosa and theca cells from the first (F1), second (F2) and third (F3) largest hierarchical follicles were dissected as previously described (Chabrolle et al. 2007a, Tosca et al. 2007). Tissues (adipose tissue, skeletal muscle and ovarian cortex) and cells (granulosa and theca) were immediately snap-frozen in liquid nitrogen and stored at $-80{ }^{\circ} \mathrm{C}$ until use for RNA and protein extraction. Granulosa cells were also used directly for culture.

Blood samples were taken from prepubertal hens (3- and 9-week-old, $n=8$ for each stage) and 52-week-old laying breed hens $(n=8$, ISA Brown, egg layer type, Institut de Selection Animale). All of the animals were fasted overnight before sampling.

\section{Isolation and culture of granulosa cells}

Granulosa cells were prepared for culture by being dispersed in $0.3 \%$ collagenase type A (Roche Diagnostic) in F12 medium containing $5 \%$ fetal bovine serum (FBS). Cells were recovered by centrifugation, washed with fresh medium, and counted in a haemocytometer. The viability of F1-F4 granulosa cells was estimated by trypan blue exclusion at about $95 \%$. The culture medium was DMEM supplemented with $100 \mathrm{U} / \mathrm{ml}$ penicillin, $100 \mathrm{mg} / \mathrm{l}$ streptomycin, $3 \mathrm{mmol} / \mathrm{l}$ L-glutamine and 5\% FBS. Cells were initially cultured for $24 \mathrm{~h}$ with no treatment, then incubated in fresh culture medium with or without test reagents for the appropriate time. All of the cultures were maintained in a water-saturated atmosphere of $95 \%$ air: $5 \% \mathrm{CO}_{2}$ at $37{ }^{\circ} \mathrm{C}$.

\section{Hormones and reagents}

Human recombinant IGF1 was obtained from Sigma. Purified ovine luteinising hormone (LH) (lot 26) and ovine follicle stimulating hormone (FSH)-20 (lot no. AFP-7028D) were obtained from Dr AF Parlow and the National Hormone and Pituitary Programme (Bethesda, MD, USA). Human recombinant full-length adiponectin and human recombinant NAMPT were obtained from R\&D Systems (Lille, France). The NAMPT inhibitor, FK866, was obtained from Sigma.

\section{Antibodies}

Rabbit polyclonal antibodies to PRKAA1 (AMPK $\alpha 1)$ were purchased from Upstate Biotechnology, Inc. (Lake Placid, NY, USA). Rabbit polyclonal antibodies to phospho-MAPK3/1 (Thr202/Tyr204), phospho-MAPK14 (Thr180/Tyr182), phosphoAKT1 (Ser 473), AKT1 and phospho-PRKAA Thr172 were obtained from New England Biolabs, Inc. (Beverly, MA, USA). Mouse MAB to vinculin (VCL) were obtained from Sigma. Rabbit polyclonal antibodies against P450 side chain cleavage, or P450SCC (CYP11A1), STAR and 3 $\beta$-hydroxysteroid dehydrogenase (HSD3B) were generously provided by 
Dr Dale Buchanan Hales (Southern Illinois University, Carbondale, IL, USA) and Dr Van Luu-The (CHUL Research Center and Laval University, Quebec, Canada) respectively. Rabbit polyclonal antibodies to MAPK1 (C14) and MAPK14 (C20) were purchased from Santa Cruz Biotechnology. All antibodies were used at 1:1000 dilution in western blotting.

\section{The production of antibodies against chicken NAMPT by AgroBio Co. (AgroBio, Orleans, France)}

One peptide corresponding to the SYSFDEVRQNARLKNSELETAC (amino acids 471-491) carboxy-terminal residues of chicken NAMPT was conjugated to keyhole limpet haemocyanin using sulphydryl chemistry. Two hundred micrograms of a mixture of two conjugated peptides were emulsified with an equal volume of complete Freund's adjuvant and injected into two New Zealand White rabbits. Secondary immunisations were performed on post-immunisation days 14, 28, 42, 56, 84 and 112 , followed by bleeding on day 127 post-immunisation.

\section{RNA extraction and RT-PCR}

Total RNA was extracted from hen granulosa and the theca cells of hierarchical follicles (F3 to F1), ovarian cortex and small white follicles (SW) on ice using an ultraturax homogeniser in TRIzol reagent according to the manufacturer's instructions (Invitrogen by Life Technologies). The total RNAs were treated with DNasel using a DNA-free Kit (Ambion by Life Technologies). The quantity of RNA was then assessed using a NanoDrop spectrophotometer. RT of total RNA ( $1 \mu \mathrm{g}$ ) was performed for $1 \mathrm{~h}$ at $37^{\circ} \mathrm{C}$ in a $20 \mu \mathrm{l}$ mixture as previously described (Coyral-Castel et al. 2010). Single-strand cDNAs of NAMPT and $\beta$ actin $(A C T B)$ were amplified with the following specific primers (Invitrogen by Life Technologies): NAMPT forward: 5'-CGT-TCA-GCC-CAT-TTG-GTG-A-3', reverse: 5'-AGT-GGTGCC-TCT-GGA-CTT-CG-3'; and ACTB forward: $5^{\prime}$-ACG-GAACCA-CAG-TTT-ATC-ATC-3', reverse: 5'-GTC-CCA-GTC-TTCAAC-TAT-ACC-3'. The PCR was carried out in a previously described mixture (Coyral-Castel et al. 2010) for 30 (ACTB) or 35 (NAMPT) PCR cycles $\left(1 \mathrm{~min}\right.$ at $94{ }^{\circ} \mathrm{C}, 1 \mathrm{~min}$ at $58{ }^{\circ} \mathrm{C}, 1 \mathrm{~min}$ at $72{ }^{\circ} \mathrm{C}$ ), with a final extension step of $7 \mathrm{~min}$ at $72{ }^{\circ} \mathrm{C}$. PCR products were visualised in $1.5 \%(\mathrm{w} / \mathrm{v})$ agarose gel stained with ethidium bromide. $\beta$ actin was used as a positive control. Finally, DNA was extracted from the agarose gel using the EZNA microelute gel extraction kit (VWR, Fontenay-sous-Bois, France) according to the manufacturer's instructions. DNA was sequenced by Beckman Coulter Genomics (Grenoble, France). RT and PCR consumables were purchased from Promega.

\section{Real-time quantitative PCR}

Targeted cDNAs were quantified by real-time quantitative PCR using SYBR Green Supermix (Bio-Rad) and $250 \mathrm{nM}$ of specific primers (Invitrogen by Life Technologies, Table 1) in a total volume of $20 \mu \mathrm{l}$ in a MyiQ Cycle device (Bio-Rad). Samples were tested in duplicate on the same plate; PCR amplification with water instead of cDNA was performed systematically as a negative control. After incubation for $2 \mathrm{~min}$ at $50{ }^{\circ} \mathrm{C}$ followed by denaturation for $10 \mathrm{~min}$ at $95^{\circ} \mathrm{C}$, samples were subjected to
Table 1 Oligonucleotide primers sequences.

\begin{tabular}{|c|c|c|}
\hline Name & Forward $5^{\prime}-3^{\prime}$ & Reverse $5^{\prime}-3^{\prime}$ \\
\hline NAMPT & $\begin{array}{l}\text { CGTTCAGCCCATTT- } \\
\text { GGTGA }\end{array}$ & AGTGGTGCCTCTGGACTTCG \\
\hline$A C T B$ & $\begin{array}{l}\text { ACGGAACCACAGTT- } \\
\text { TATCATC }\end{array}$ & GTCCCAGTCTTCAACTATACC \\
\hline RPL-15 & $\begin{array}{l}\text { TGTGATGCGTTTCC- } \\
\text { TCCTTGG }\end{array}$ & CCATAGGTTGCACCTTTTGGG \\
\hline EEF1A & $\begin{array}{l}\text { AGCAGACTTTGTGA- } \\
\text { CCTTGCC }\end{array}$ & TGACATGAGACAGACGGTTGC \\
\hline
\end{tabular}

40 cycles $\left(30 \mathrm{~s}\right.$ at $95^{\circ} \mathrm{C}, 30 \mathrm{~s}$ at $60^{\circ} \mathrm{C}, 30 \mathrm{~s}$ at $\left.72{ }^{\circ} \mathrm{C}\right)$, and then the melting curve was acquired. Primer efficiency $(\mathrm{E})$ was assessed from serial dilutions of a pool of cDNA obtained from the samples and ranged from 1.8 to 2.0. Three reference genes were used: ACTB, RPL15 and EEF1A1 (Table 1). Gene expression was quantified separately for each gene using the formula $E^{-C q}$. The expression of NAMPT was measured relative to the geometric mean of the expression of the three reference genes.

\section{Protein extraction and western blot}

Lysates of tissues (adipose tissue and muscle) and cells were prepared on ice with an ultraturax homogeniser in lysis buffer as previously described (Coyral-Castel et al. 2010). Proteins extracts $(80 \mu \mathrm{g})$ were denatured, subjected to electrophoresis in a $12 \%(\mathrm{w} / \mathrm{v})$ SDS-PAGE, transferred onto nitrocellulose membrane and then incubated with specific antibodies as previously described (Coyral-Castel et al. 2010). Proteins were detected by enhanced chemiluminescence (Western Lightning Plus-ECL, PerkinElmer, Courtaboeuf, France) using a G:Box SynGene (Ozyme, Montigny-le-Bretonneux, France) with the GeneSnap software version 7.09.17. Signals were quantified with the GeneTools software version 4.01.02.

\section{Measurement of progesterone secretion by granulosa cells}

Progesterone concentration in hen granulosa cells was determined in serum-free media after culturing for $24 \mathrm{~h}$ in the presence or absence of $76 \mathrm{ng} / \mathrm{ml}$ NAMPT \pm IGF1, $300 \mathrm{ng} / \mathrm{ml}$ $\mathrm{FSH}$ or $300 \mathrm{ng} / \mathrm{ml} \mathrm{LH}$. Initially, granulosa were grown in 48-well dishes $\left(1.25 \times 10^{5}\right.$ viable cells/250 $\mu$ medium per well) in DMEM and 5\% FBS for $24 \mathrm{~h}$. After overnight serum starvation, granulosa cells were incubated with the appropriate treatment for $48 \mathrm{~h}$. The concentration of progesterone derived from hen granulosa cells, in the culture media was measured using an ELISA protocol as previously described (Canepa et al. 2008). The intra-assay coefficient of variation (CV) averaged $<10 \%$. The results are expressed as the amount (mean \pm s.E.M.) of steroid $(\mathrm{ng} / \mathrm{ml})$ secreted per $48 \mathrm{~h}$. There were four replicates for each treatment within each culture, and we performed four cultures. In each culture, we used four hens, and consequently we used a pool of granulosa cells from four follicles of the same category (granulosa cells from one follicle per hen).

\section{Thymidine incorporation into granulosa cells}

After $18 \mathrm{~h}$ of serum starvation, the culture medium was removed and $1 \mu \mathrm{Ci} / \mathrm{ml}$ of $\left[{ }^{3} \mathrm{H}\right]$ thymidine (Perkin-Elmer) was 
added in the presence or absence of 10 or $100 \mathrm{ng} / \mathrm{ml}$ NAMPT $\pm 76 \mathrm{ng} / \mathrm{ml}$ IGF1 in enriched McCoy's 5A. After culturing for $24 \mathrm{~h}$, excess thymidine was removed by washing twice with PBS $1 \times$. The cells were then fixed using cold $50 \%(\mathrm{v}: \mathrm{v})$ trichloroacetic acid for 10 min and lysed with $0.5 \mathrm{M} \mathrm{NaOH}$. Radioactivity was determined in scintillation fluid by counting in a $\beta$-photomultiplier. Values are expressed as count per min (CPM). There were four replicates for each treatment within each culture, and we performed five cultures. In each culture, we used four hens, and we consequently used a pool of granulosa cells from four follicles of the same category (granulosa cells from one follicle per hen).

\section{Immunocytochemistry}

Hen granulosa cells were collected from hierarchical follicles (F1). They were then fixed with $4 \%$ paraformaldehyde in PBS $(\mathrm{pH} 7.4)$ for $10 \mathrm{~min}$ and washed three times with PBS. The fixed cells were then permeabilised with sodium citrate $(0.1 \%)$ in $0.1 \%$ Triton $\mathrm{X}-100$ for $2 \mathrm{~min}$ at $4{ }^{\circ} \mathrm{C}$. Endogenous peroxidases were blocked in methanol with $3 \% \mathrm{H}_{2} \mathrm{O}_{2}$ for $10 \mathrm{~min}$ at room temperature non-specific background was eliminated by blocking in PBS with 5\% horse serum for $20 \mathrm{~min}$, followed by incubation overnight at $4{ }^{\circ} \mathrm{C}$ with PBS containing rabbit primary antibody raised against NAMPT (1/100). Sections were washed twice for $5 \mathrm{~min}$ in a PBS bath, then incubated for 30 min with a second antibody (HRP anti-rabbit antibody). After this, the sections were again washed twice for $5 \mathrm{~min}$ in a PBS bath. Staining was revealed by incubation at room temperature with DAB. Immunospecific staining was brown if NAMPT was present. Finally, the sections were counterstained with haematoxylin. Slides were observed under an Axioplan Zeiss transmission microscope.

\section{NAD+ and NADH quantification}

The concentrations of NAD + and NADH in cell lysates were evaluated using a NAD+/NADH Quantification Kit (Bio Vision, Lyon, France) according to the manufacturer's instructions. The amount of NAD + in each sample was normalised to the protein content for each test sample.

\section{Hen NAMPT ELISA}

Blood samples were collected from the occipital venous sinus in heparin blood collection tubes. Plasma samples were obtained by centrifugation (3000 $\mathrm{g}$ for $15 \mathrm{~min}$ at $4{ }^{\circ} \mathrm{C}$ ) and stored at $-20{ }^{\circ} \mathrm{C}$ until analysed. Before the visfatin ELISA assay, plasma samples were again centrifuged $(10000 \boldsymbol{g}$ for $10 \mathrm{~min}$ at $4{ }^{\circ} \mathrm{C}$ ) to remove most of the lipids (observed mainly in the sexually mature hen). Chicken plasma NAMPT levels were determined using a commercially available chicken NAMPT ELISA (Hölzel Diagnostika, Köln, Germany; reference no. E12V0003, 96 tests) according to the manufacturer's protocol, with an intra-assay CV of $<6 \%$. Briefly, $100 \mu \mathrm{l}$ of standard or sample was added to the appropriate well in the antibody precoated microtitre plate. Then, $50 \mu$ l of conjugate enzyme was added to each well and the plate was incubated for $1 \mathrm{~h}$ at $37^{\circ} \mathrm{C}$. After washing, $50 \mu \mathrm{l}$ of substrate A and $50 \mu$ l of substrate
$\mathrm{B}$ were added, and the plate was again incubated for $15 \mathrm{~min}$ at $37^{\circ} \mathrm{C}$. At this point, the reaction was stopped using $50 \mu \mathrm{l}$ of stop solution, and the optical density was immediately determined at $450 \mathrm{~nm}$.

\section{Statistical analysis}

All experimental data are presented as means \pm S.E.M. One-way ANOVA was used to test for: differences in plasma NAMPT at different ages in progesterone secretion in response to different concentrations of rhVisf and in response to rhVisf $(100 \mathrm{ng} / \mathrm{ml})$ in the presence or absence of IGF1, FSH and $\mathrm{LH}$; in NAD+ concentration in response to different doses of FK866; in STAR/VCL HSD3B/VCL and CYP11A1 in response to rhVisf in the presence or absence of IGF1 or FK866; in phosphoMAPK1/MAPK1 in response to different times of stimulation of rhVisf or in response to rhVisf in the presence or absence of IGF1 or FK866; and in tritiated thymidine incorporation in response to different doses of rhVisf in the presence or absence of IGF1. Two-way ANOVA was used to test for differences in NAMPT expression in theca and granulosa cells at different follicle developmental stages and in progesterone secretion in the presence or absence of rhVisf and IGF1 with or without FK866. The level of statistical significance was set at $P<0.05$. Statview software (Cary, NC, USA) was used for all statistical tests.

\section{Results}

\section{NAMPT expression in hen ovarian cells}

We determined the expression of NAMPT in ovarian cortex, theca and granulosa cells from each type of hierarchical follicle studied (F3 to F1) and in SW. As shown in Fig. 1A, we used RT-PCR to amplify one cDNA fragment of $302 \mathrm{bp}$, which corresponds to NAMPT. The specificity of the amplified product was assessed by sequencing. Using a chicken NAMPT antibody, we revealed the presence of NAMPT (52 kDa) by immunoblotting protein extracts from theca and granulosa cells derived from hierarchical follicles (F3 to F1, Fig. 1B). The chicken NAMPT antibody was produced by immunising two rabbits with a 21-amino acid peptide that corresponded to a highly variable region of chicken NAMPT located at the carboxy-terminal end of the mature protein (Supplementary Figure $1 \mathrm{~A}$, see section on supplementary data given at the end of this article). When it was used in western immunoblotting, the antiserum detected an $\sim 52 \mathrm{kDa}$ protein in chicken plasma, white abdominal adipose tissues and skeletal muscle lysates that were resolved by reducing with SDSPAGE (Supplementary Figure 1B). We demonstrated the specificity of the antiserum by showing that the $52 \mathrm{kDa}$ signal in chicken plasma, white adipose tissue and muscles lysates were eliminated when immunoblotting was performed in the presence of pre-immune rabbit serum or in the absence of chicken NAMPT antiserum (Supplementary Figure 1B). Immunocytochemistry with hen granulosa cells from F1 hierarchical follicles 

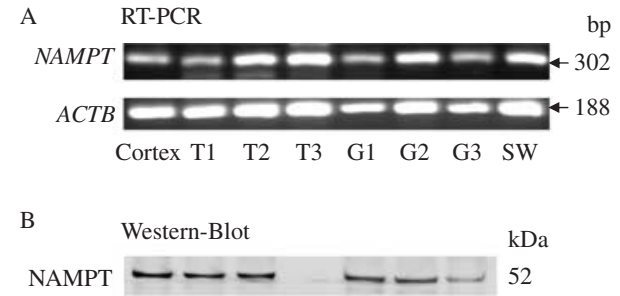

Ponceau staining

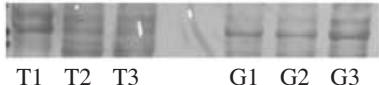

C Immunocytochemistry
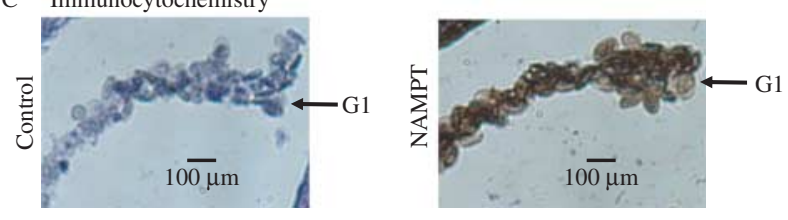

Figure 1 NAMPT expression in ovarian cells. (A) Amplification by RT-PCR of NAMPT (302 bp) in ovarian cortex, small white follicles and granulosa (G1 to G3) and theca (T1 to T3) cells of the third largest hierarchical follicles (F3 to F1) in hens. (B) Protein expression determined by immunoblotting of NAMPT in granulosa (G1 to G3) and theca (T1 to T3) cells. (C) Immunocytochemistry of NAMPT in granulosa cells from $\mathrm{F} 1$ hierarchical follicles. The pictures are representative of results obtained in four animals.

confirmed the results obtained by immunoblotting (Fig. 1C). We therefore concluded that NAMPT is present in ovarian cortex, granulosa and theca cells from hierarchical follicles.

\section{The evolution of NAMPT expression with follicular development}

Developmental changes in the expression of NAMPT mRNA and protein during follicle development were investigated in both granulosa and theca cells from hierarchical follicles (F3 to F1) using real-time RT-PCR and western blotting respectively. As shown in Fig. 2A, NAMPT mRNA expression was significantly higher in granulosa cells than it was in theca cells in F1 and F2 hierarchical follicles, but in F3 hierarchical follicles, the level of expression was similar in the two cell types. In theca cells, there was a clear decrease in the expression of NAMPT mRNA as the follicle developed, whereas it remained stable in granulosa cells (Fig. 2A). Using immunoblotting, we demonstrated that the NAMPT protein content of theca cells was almost twice that of granulosa cells. NAMPT protein levels were unaffected by follicular development in both theca and granulosa cells.

\section{Quantification of plasma NAMPT levels by ELISA and immunoblotting in young prepubertal and adult hens}

We next determined plasma NAMPT levels in young prepubertal (3- and 9-week-old) hens and in laying adult (52-week-old, the same age as the hens used for in vitro culture of granulosa cells) hens. NAMPT levels in the plasma collected from the adult animals were significantly lower than those in the plasma from young prepubertal (3-week-old) hens (Fig. 3A). Similar results were found using western blotting (Fig. 3B).

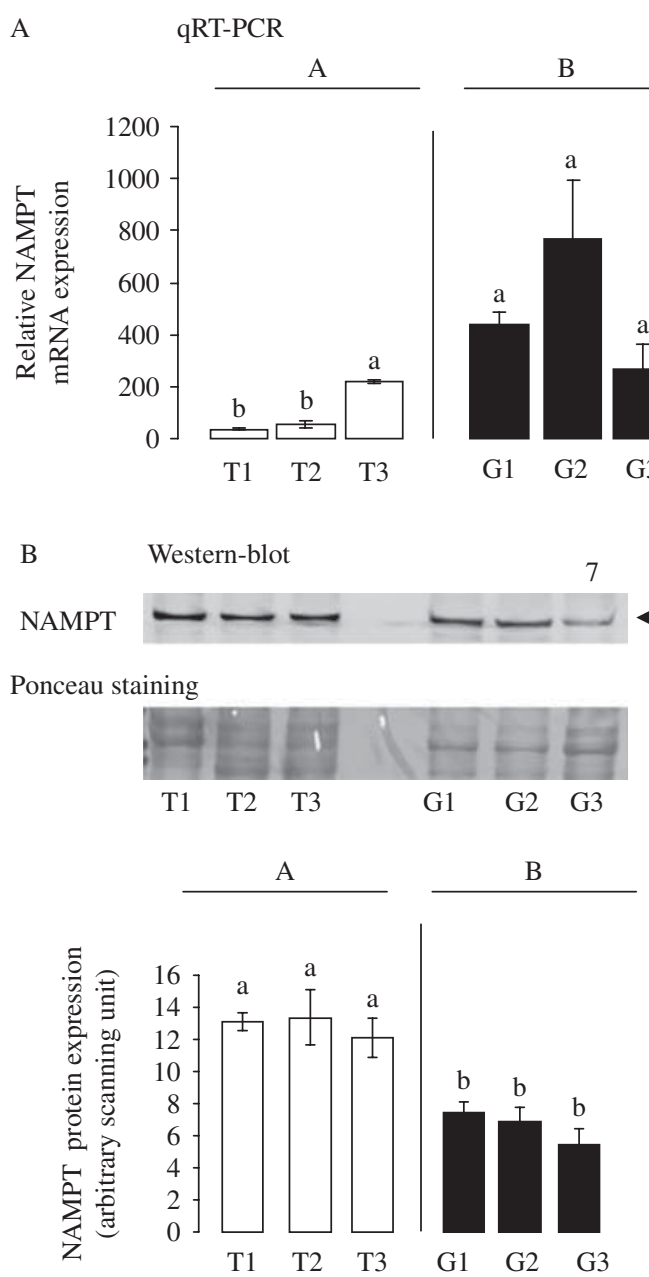

Figure 2 NAMPT expression during follicular maturation. (A) Relative expression of NAMPT mRNA in theca and granulosa cells from the third largest hierarchical follicles in hens, based on real-time RT-PCR. Total RNA from all types of ovarian cells and hierarchical follicles was treated with DNAse and reverse transcribed as described in the Materials and methods. cDNAs were used in separate real-time quantitative PCR analyses of NAMPT mRNA or reference genes, and SYBR green was used as the dye. NAMPT expression was measured relative to the geometric mean of the expression of three reference genes as described in the Materials and methods. (B) Western blotting was used to determine the protein levels of NAMPT in theca and granulosa cells from the third largest hierarchical follicles of hens. Ponceau staining was used as a loading control. The data represent mean values from seven hens for each ovarian cell and hierarchical follicle. Different capital letters indicate a significant effect $(P<0.05)$ of cell type (granulosa vs theca cells), whereas lowercase letters indicate a significant effect of follicular developmental stage. 
A

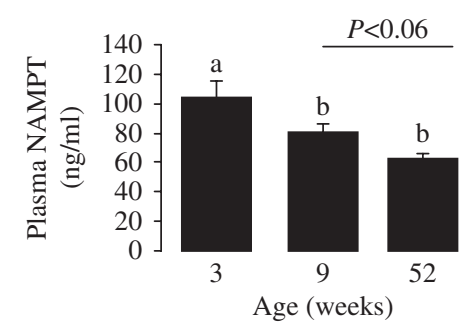

B

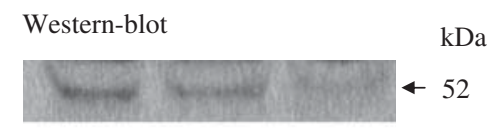

Ponceau staining
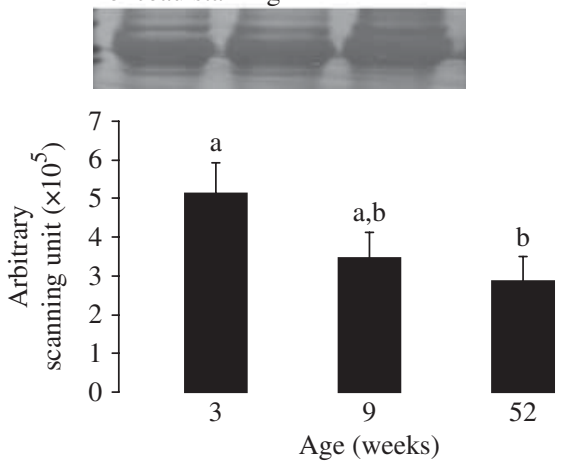

Figure 3 Plasma NAMPT levels determined by ELISA (A) and westernblot (B) in hens at 3, 9 and 52 weeks. (A) Plasma NAMPT levels in prepubertal (3- or 9-week-old) and adult (52-week-old) hens based on ELISA. All serums samples that were used in western blotting (B) contained equal amounts of protein; this was confirmed by staining the nitrocellulose membrane with Ponceau. Blots were quantified using an arbitrary scale. The letters above each bar indicate significant differences $(P<0.05)$. Data are represented as means \pm S.E.M. ( $n=8$ /age group).

\section{The effects of recombinant human NAMPT on progesterone secretion in granulosa cells from hierarchical follicles}

To determine whether NAMPT is involved in steroidogenesis, we investigated the effect of human recombinant NAMPT (rhVisf) on progesterone production in granulosa cells from F1 (Fig. 4A and B), F2 and F3/4 (data not shown) hierarchical follicles. We used human recombinant NAMPT because chicken NAMPT protein is highly homologous to human NAMPT $(93 \%$ amino acid identity; Krzysik-Walker et al. 2008). Granulosa cells from F1 hierarchical follicles were incubated in serum-free medium with different concentrations of rhVisf $(0,1,10,100$ or $500 \mathrm{ng} / \mathrm{ml}$; Fig. 4A) or with $100 \mathrm{ng} / \mathrm{ml} \mathrm{rhVisf}$ in the presence or absence of IGF1 $(76 \mathrm{ng} / \mathrm{ml}), \mathrm{FSH}(300 \mathrm{ng} / \mathrm{ml})$ or $\mathrm{LH}(300 \mathrm{ng} / \mathrm{ml})$ for $48 \mathrm{~h}$ (Fig. 4B). The secretion of progesterone was inhibited by NAMPT treatment in a dose-dependent manner (Fig. 4A). As expected, IGF1 $(76 \mathrm{ng} / \mathrm{ml}), \mathrm{FSH}(300 \mathrm{ng} / \mathrm{ml})$ and $\mathrm{LH}(300 \mathrm{ng} / \mathrm{ml})$ significantly increased the production of progesterone by granulosa cells (Chabrolle et al. 2007a). RhVisf produced a more than twofold reduction in IGF1-induced progesterone secretion but did not affect the response to $\mathrm{LH}$ or FSH (Fig. 4B). Similar results were observed in granulosa cells from F2 and F3/4 hierarchical follicles (data not shown).

\section{The effects of FK866 on rhVisf-inhibited production of progesterone in hen granulosa cells}

We confirmed the effect of NAMPT on IGF1-induced steroid production using FK866, a specific inhibitor of NAMPT enzyme activity in granulosa cells from F1 hierarchical follicles. First, we demonstrated that $10 \mathrm{nM}$ FK866 inhibited NAMPT activity, which thus caused a significant decrease in NAD+ levels (Fig. 5A). Next, we checked that the same concentration of FK866 did not induce apoptosis using the trypan blue exclusion method and annexin $\mathrm{V}$ labelling in hen granulosa cells (data not shown). FK866 completely abolished the inhibitory effect of NAMPT on IGF1-induced progesterone secretion (Fig. 5B). Similar results were obtained using granulosa cells from F2 and F3/4 hierarchical follicles (data not shown). We therefore conclude that NAMPT treatment inhibits IGF1-stimulated production of progesterone in hen granulosa cells.

We next used hen granulosa cells from F1 hierarchical follicles to examine whether the inhibitory effect of NAMPT on progesterone production was a result of its effects on an important cholesterol carrier, STAR, or on two enzymes involved in steroidogenesis, HSD3B and CYP11A1. NAMPT treatment $(100 \mathrm{ng} / \mathrm{ml})$ in the

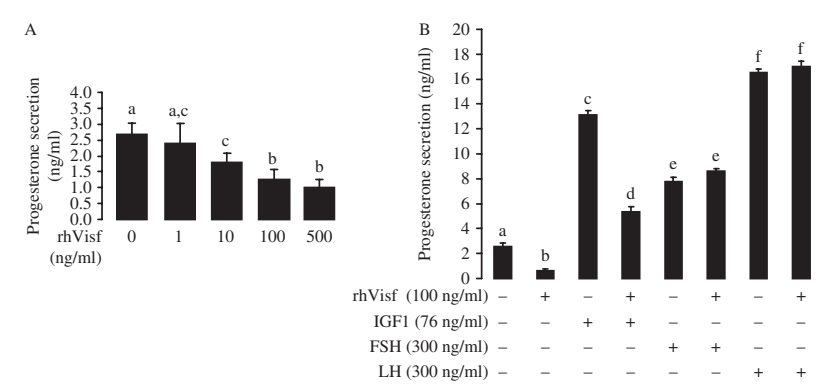

Figure 4 Effects of recombinant human NAMPT (rhVisf) on progesterone secretion in granulosa cells from F1 hierarchical follicles. Granulosa cells from the largest pre-ovulatory follicles were cultured for $24 \mathrm{~h}$ in medium with serum and then in serum-free medium for $48 \mathrm{~h}$ with different concentrations of $\operatorname{rhVisf}(0,1,10,100$ or $500 \mathrm{ng} / \mathrm{ml})(\mathrm{A})$ or with $100 \mathrm{ng} / \mathrm{ml} \mathrm{rhVisf} \mathrm{in} \mathrm{the} \mathrm{presence} \mathrm{or} \mathrm{absence} \mathrm{of} \mathrm{IGF1}(76 \mathrm{ng} / \mathrm{ml})$, FSH $(300 \mathrm{ng} / \mathrm{ml})$ or $\mathrm{LH}(300 \mathrm{ng} / \mathrm{ml})(\mathrm{B})$, as described in Materials and methods. The culture medium was then collected, and its progesterone content ( $\mathrm{A}$ and $\mathrm{B}$ ) was determined by ELISA. Results (means \pm s.E.M.) from four independent experiments are expressed in $\mathrm{ng} / \mathrm{ml}$. There were four replicates for each treatment within each experiment. In each experiment, we used four hens, and we consequently used a pool of granulosa cells from four follicles of the same category (granulosa cells from one follicle per hen). Bars with different letters are significantly different $(P<0.05)$. 


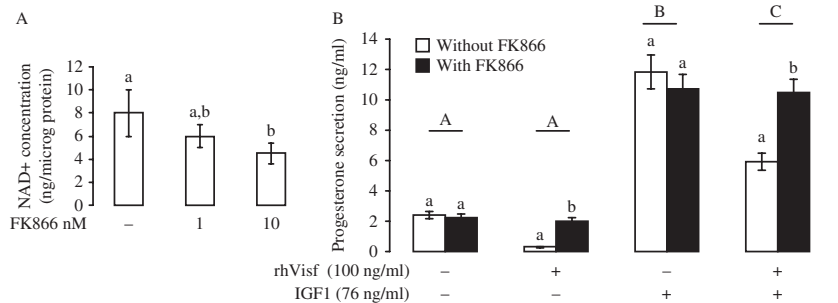

Figure 5 The effect of FK866 on NAMPT activity (A) and on the inhibitory effect of rhVisf on progesterone secretion (B) in granulosa cells from hierarchical follicle F1. (A) Granulosa cells from the largest hierarchical follicles were cultured for $24 \mathrm{~h}$ in medium with serum and then in serum-free medium for $48 \mathrm{~h}$ in the presence of FK866 ( 1 or $10 \mathrm{nM}$ ), an enzymatic inhibitor of NAMPT. Granulosa cells were then lysed, and the amount of NAD + was determined as described in Materials and methods and represented as NAD + production per ng of total protein. Results are means \pm s.E.M. from four independent experiments. Bars with different letters are significantly different $(P<0.05)$. (B) Granulosa cells from the largest hierarchical follicles were cultured for $24 \mathrm{~h}$ in medium with serum and then in serum-free medium for $48 \mathrm{~h}$ in the presence or absence of rhVisf with or without IGF1 (76 ng/ml) and FK866 (10 nM), as described in Materials and methods. The culture medium was then collected, and its progesterone content was analysed by ELISA. Results (means \pm s.E.M.) from four independent experiments are expressed in $\mathrm{ng} / \mathrm{ml}$. There were four replicates for each treatment within each experiment. In each experiment, we used four hens, and we consequently used a pool of granulosa cells from four follicles of the same category (granulosa cells from one follicle per hen). Bars with different letters are significantly different $(P<0.05)$.

presence or absence of IGF1 halved the amount of STAR (Fig. 6A) and HSD3B (Fig. 6B), but it did not affect CYP11A1 protein expression (Fig. 6C). Furthermore, these effects were eliminated in the presence of FK866 (Fig. 6A and B). The results indicate that the decrease in progesterone secretion following NAMPT treatment may be a result of the reduced production of the STAR and HSD3B proteins.

\section{Signalling pathways involved in the NAMPT effects in hen granulosa cells}

It is well known that NAMPT treatment activates various signalling pathways, including PRKA, AKT1, MAPK3/1 and MAPK14, in different cell types (Cheng et al. 2011, Brandauer et al. 2013, Reverchon et al. 2013a, Song et al. 2014). We showed that in hen granulosa cells from F1 hierarchical follicles, NAMPT treatment decreased MAPK3/1 phosphorylation after 30 or 60 min of stimulation (Fig. 7A). Consistent with previous research using chicken cells (Tosca et al. 2006), phosphorylated MAPK3/1 appeared as a single band $(\sim 42 \mathrm{kDa})$ and probably corresponded to MAPK1. Under the same conditions, PRKA, AKT1 and MAPK14 phosphorylation levels were unchanged (data not shown). We next assessed the effects of NAMPT treatment on IGF1-induced MAPK3/1 phosphorylation (Fig. 7B). Hen granulosa cells from F1 hierarchical follicles were incubated in serum-free medium supplemented with recombinant human NAMPT $(100 \mathrm{ng} / \mathrm{ml})$ for $48 \mathrm{~h}$ (the procedure used to measure progesterone production) and were then treated with or without IGF1 $(76 \mathrm{ng} / \mathrm{ml})$ for $5 \mathrm{~min}$. As expected, IGF1 treatment
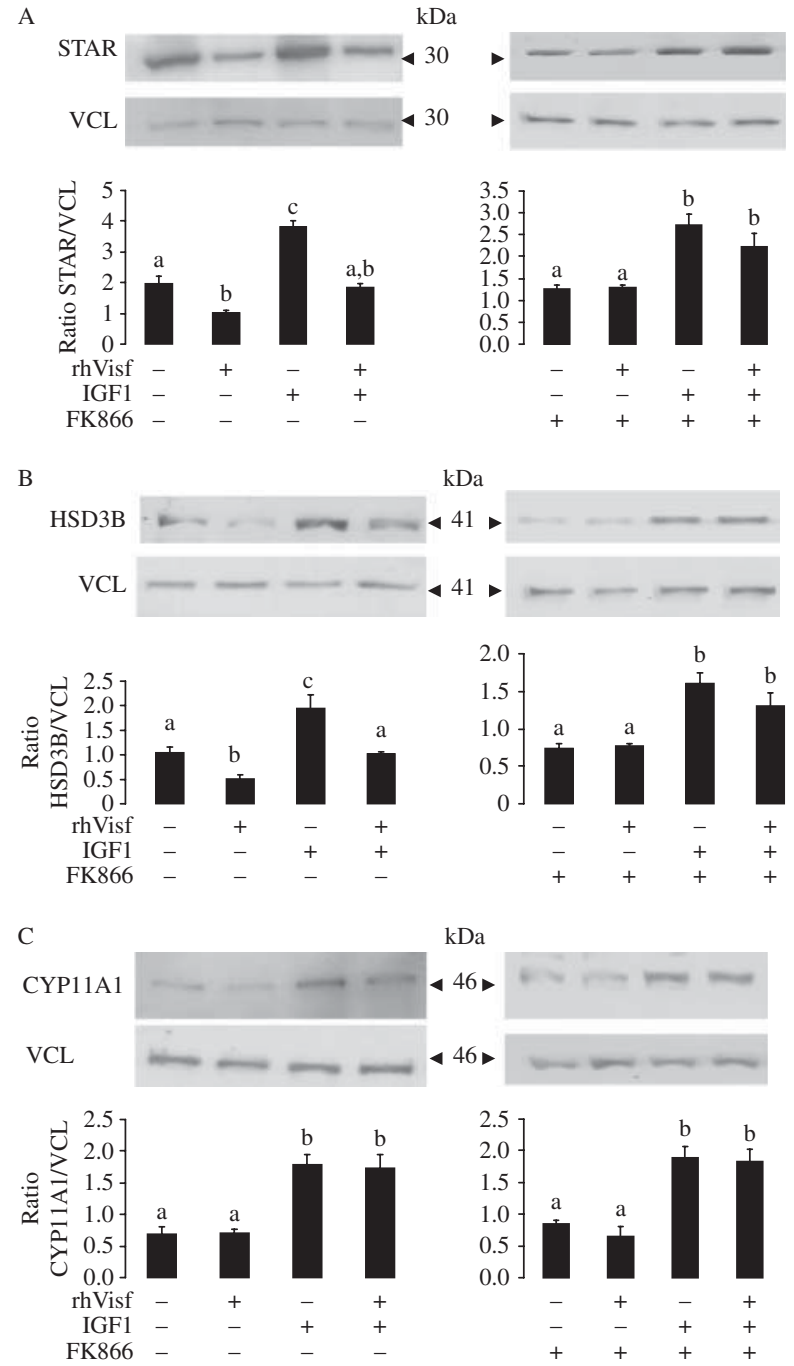

Figure 6 The effect of rhVisf on the amounts of the STAR (A), HSD3B (B) and CYP11A1 (C) proteins in granulosa cells from hierarchical follicles $\mathrm{F} 1$ in the absence or presence of FK866. Protein extracts from hen granulosa cells from F1 hierarchical follicles were cultured for $48 \mathrm{~h}$ with rhVisf in the presence or absence of IGF1 $(76 \mathrm{ng} / \mathrm{ml})$ with or without FK866 (10 nM), then subjected to SDS-PAGE as described in Materials and methods. They were then transferred onto nitrocellulose membranes and incubated with antibodies raised against the STAR (A), HSD3B (B) and CYP11A1 (C) proteins. We verified the similarity of protein loads by re-probing the membrane with an anti-vinculin antibody. Results are representative of at least four independent experiments. Blots were quantified, and the STAR, HSD3B and CYP11A1/VCL ratios are shown. The results are expressed as means \pm S.E.M. from three independent experiments. Bars with different letters are significantly different $(P<0.05)$. 
A

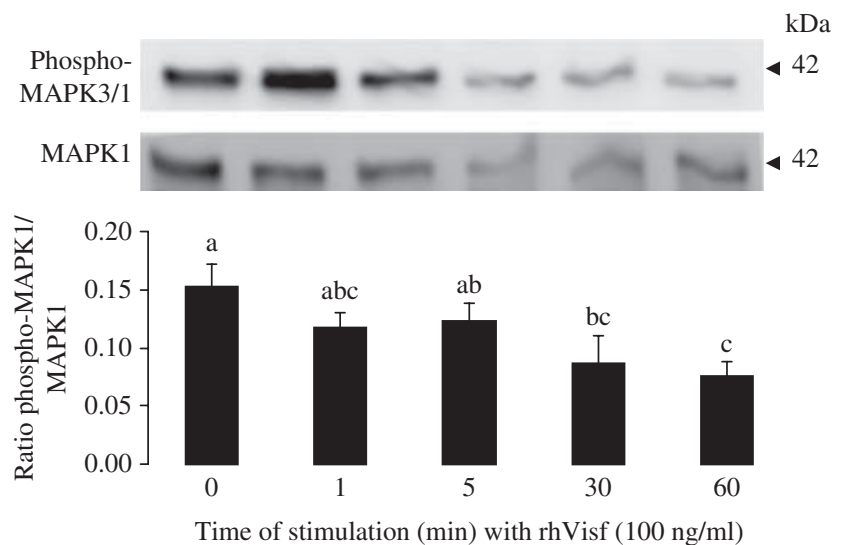

B

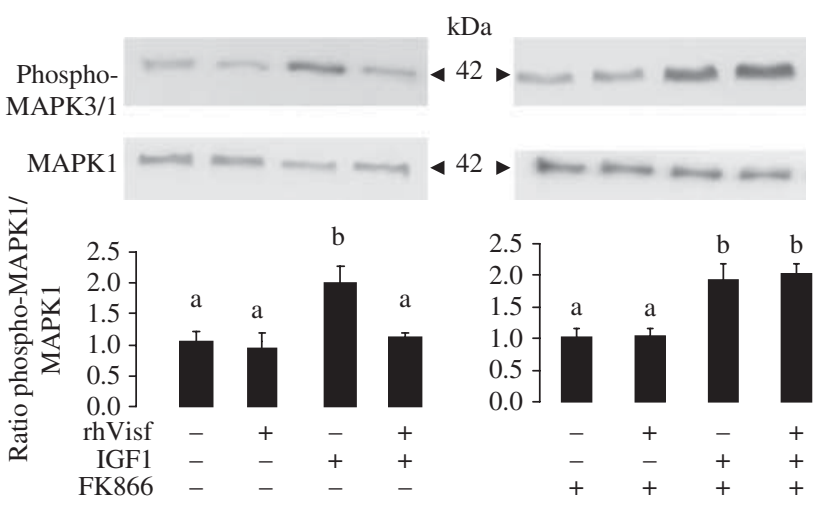

Figure 7 The effect of rhVisf on basal (A) and IGF1-induced (B) levels of MAPK3/1 phosphorylation in granulosa cells from F1 hierarchical follicles. Granulosa cell lysates were prepared from cells incubated for $48 \mathrm{~h}$ with rhVisf $(100 \mathrm{ng} / \mathrm{ml})$ for varying periods of $0,1,5,10,30 \mathrm{or} 60 \mathrm{~min}(\mathrm{~A})$ or rhVisf $(100 \mathrm{ng} / \mathrm{ml})$ in the presence or absence of FK866 (10 nM) (B) and then stimulated with IGF1 $(76 \mathrm{ng} / \mathrm{ml})$ for 5 min. Lysates (80 $\mu$ g) were resolved using SDS-PAGE, transferred to nitrocellulose and probed with anti-phospho-MAPK3/1 and anti-MAPK3/1 total. Representative blots from three independent experiments are shown. Bands on the blots were quantified, and the ratio of phosphorylated protein:total protein is shown. The results are reported as means \pm S.E.M. Bars with different letters are significantly different $(P<0.05)$.

alone significantly increased phosphorylation of MAPK3/1. Treatment with recombinant human NAMPT alone did not affect basal phosphorylation of MAPK3/1, although it completely eliminated IGF1-induced phosphorylation of MAPK3/1. Furthermore, this effect was abolished when the cells were incubated with $10 \mathrm{ng} / \mathrm{ml}$ FK866 (Fig. 7B). In summary, acute (30 or $60 \mathrm{~min}$ ) NAMPT treatment reduces MAPK3/1 phosphorylation and inhibits IGF1-induced MAPK3/1 phosphorylation in hen granulosa cells.

\section{The effects of NAMPT on granulosa cell proliferation and viability}

We also investigated whether or not treatment with NAMPT affected the number of granulosa cells in culture by inducing mitosis or altering cell viability by assessing the incorporation of $\left[{ }^{3} \mathrm{H}\right]$ thymidine into hen granulosa cells from $\mathrm{F} 1$ hierarchical follicles after culturing for $24 \mathrm{~h}$ in the presence or absence of NAMPT (10 or $100 \mathrm{ng} / \mathrm{ml}$ ) and/or IGF1 $(76 \mathrm{ng} / \mathrm{ml})$ in serum-free medium. Treatment with IGF1 $(76 \mathrm{ng} / \mathrm{ml}, 24 \mathrm{~h})$ produced a roughly fivefold increase in $\left[{ }^{3} \mathrm{H}\right]$ thymidine incorporation $(P<0.05)$ (Fig. 8). NAMPT treatment (10 or $100 \mathrm{ng} / \mathrm{ml}$ ) did not affect the level of $\left[{ }^{3} \mathrm{H}\right]$ thymidine incorporation regardless of the presence or absence of IGF1. Staining with trypan blue revealed that NAMPT treatment (10 or $100 \mathrm{ng} / \mathrm{ml}$ for 24 or $48 \mathrm{~h}$ ) had no effect on cell viability regardless of the presence or absence of IGF1 (data not shown). Similar results were obtained in granulosa cells from F2 and F3/4 hierarchical follicles. We therefore concluded that NAMPT does not alter cell proliferation in primary hen granulosa cells.

\section{Discussion}

The present study has provided the first evidence that NAMPT is present in hen ovarian follicle cells. NAMPT (mRNA and protein) is expressed in granulosa and theca cells from hierarchical follicles. Plasma NAMPT levels are higher in young hens than they are in adults. We showed that in primary hen granulosa cells, treatment with recombinant human NAMPT inhibited basal and IGF1-induced levels of progesterone secretion, and this effect was associated with a reduction in STAR and HSD3B protein levels and in MAPK3/1 phosphorylation.

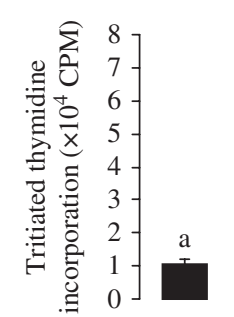

rhVisf $(\mathrm{ng} / \mathrm{ml}) \quad-$ IGF1 $(76 \mathrm{ng} / \mathrm{ml}) \quad-$
10

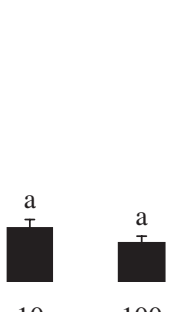

100

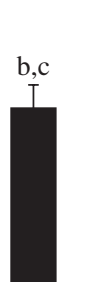

$+$

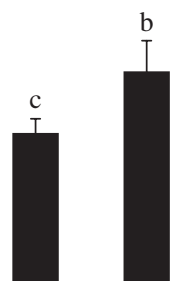

$10 \quad 100$
Figure 8 Effects of NAMPT (rhVisf) on hen granulosa cell proliferation. The incorporation of thymidine was evaluated in hen granulosa cell from F1 hierarchical follicles. Hen granulosa cells were cultured for $24 \mathrm{~h}$ with various doses of $\operatorname{rhVisf}(0,10$ or $100 \mathrm{ng} / \mathrm{ml})$ in the presence or absence of IGF1 (76 ng/ml) in serum-free medium, as described in Materials and methods. Results are representative of four independent experiments. There were four replicates for each treatment within each experiment. In each experiment, we used four hens, and we consequently used a pool of granulosa cells from four follicles of the same category (granulosa cells from one follicle per hen). The results are expressed as means \pm S.E.M. Bars with different letters are significantly different $(P<0.05)$. 
Furthermore, all of these effects were abolished when cells were incubated with FK866, which indicates that they are dependent on the enzymatic function of NAMPT.

The present study demonstrated that NAMPT is present in granulosa and theca cells from hen hierarchical follicles. NAMPT is also expressed in human and mouse ovarian cells, including oocyte, granulosa and theca cells (Park et al. 2011, Reverchon et al. 2013a). It has also been shown that in the human granulosa cell line KGN, NAMPT is induced by another adipokine named INTELECTIN 1 (Reverchon et al. 2013a). In chickens, NAMPT mRNA transcripts have been detected in various tissues, including male and female gonadal tissue (ovaries and testes) (Ons et al. 2010). In chicken testes, the levels of NAMPT mRNA expression are higher in adults than they are in prepubertal animals. In adult chickens, NAMPT has been localised to several types of testicular cells (Leydig cells, Sertoli cells, germinal cells with the exception of spermagonial cells) as well as seminal plasma and sperm. The present study is the first to show that levels of NAMPT mRNA expression are higher in granulosa cells than they are in theca cells; however, we observed the opposite pattern at the protein level, which suggests that there is translational regulation of NAMPT mRNA or differential turnover of NAMPT protein and RNA in granulosa and theca cells. The differential regulation of mRNA and protein levels of NAMPT has already been demonstrated in chickens; Ocón-Grove et al. (2010) showed that testicular NAMPT mRNA levels were higher in adult chickens than they were in prepubertal birds, whereas NAMPT protein levels were similar at both developmental stages. Previous research has shown that in hens, other adipokines, including ADIPOQ (adiponectin) protein, are also expressed at higher levels in theca cells than they are in granulosa cells (Chabrolle et al. 2007a), and similar patterns of results have been reported in human subjects (Chabrolle et al. 2009) and rodents (Chabrolle et al. 2007b). In the present study, we detected a reduction in plasma NAMPT levels as hens aged; however, it has been reported that in broiler chickens, plasma NAMPT levels increase between 4 and 8 weeks of age (Krzysik-Walker et al. 2008), and higher NAMPT plasma levels have been detected in adult (29-week-old) chickens than in prepubertal (4- and 14-week-old) male chickens (Ocón-Grove et al. 2010). These results suggest that the regulation of NAMPT levels during development varies according to sex and breed (meat vs laying) of the chickens. These hypotheses need to be confirmed in larger samples.

In the present study, we observed in vitro that recombinant human NAMPT inhibited basal and IGF1induced progesterone secretion by granulosa cells. We used recombinant human NAMPT because the deduced amino acid sequence of full-length chicken NAMPT is 92-93\% homologous with human NAMPT (KrzysikWalker et al. 2008). Furthermore, we stimulated primary hen granulosa cells with a dose of $100 \mathrm{ng} / \mathrm{ml}$ NAMPT, which is close to the level observed in plasma. The effect of NAMPT on hen granulosa cell steroidogenesis in vitro appears to be different from that observed in human granulosa cells. Our laboratory has previously shown that NAMPT stimulates IGF1-induced progesterone secretion (Reverchon et al. 2013a). This difference between species could be related to the peculiarities of chicken glucose metabolism. In spite of having 'normal' levels of circulating insulin, chickens have high glycaemia levels and show lower sensitivity to exogenous insulin as compared to humans (Simon 1989, Akiba et al. 1999, Dupont et al. 2004, Braun \& Sweazea 2008). The inhibitory effect of NAMPT on IGF1-induced progesterone production is dependent on the intracellular enzymatic activity of NAMPT as it is abolished by the pharmacological competitive inhibitor FK866 (10 nM). The results presented here are consistent with recent data showing that extracellular NAMPT has NAMPT enzymatic activity in mice (Zhao et al. 2014). Moreover, the present results suggest that NAMPT may play a role in ovulation in hens; it has already been shown that progesterone triggers ovulation in birds, which causes a surge in LH production (Sauveur \& de Reviers 1988). One hypothesis for this is that a decrease in NAMPT plasma levels before the increase in progesterone secretion is responsible for the pre-ovulatory LH surge; however, cyclical changes in the plasma levels of NAMPT in hens have yet to be determined. We also demonstrated that FK866 (10 nM) significantly decreased levels of $\mathrm{NAD}+$ in hen granulosa cells. NAMPT is the rate-limiting enzyme in NAD biosynthesis, and it plays a critical role in several mammalian physiological processes (Revollo et al. 2004, Imai 2009). In mammals, NAMPT regulates the activity of the sirtuin 1 (SIRT1) histone deacetylase (Revollo et al. 2004), and it has been shown to be involved in the regulation of steroidogenesis (Morita et al. 2012, Wu et al. 2012). Sirtuins have not yet been identified in hen ovaries, but they may play a role in the effects of NAMPT on hen granulosa cell steroidogenesis.

In the present study, we showed that recombinant human NAMPT significantly reduced protein levels of the cholesterol carrier STAR, which regulates steroidogenesis within pre-ovulatory follicles (Stocco 2001) and HSD3B in primary hen granulosa cells. These effects could explain the inhibitory effect of rhVisf on progesterone production. We also observed that acute treatment with rhVisf reduced MAPK3/1 phosphorylation but did not affect PRKA, AKT1 or MAPK14. Treatment with rhVisf also reduced IGF1-induced MAPK3/1 phosphorylation. Several studies in mammals and chickens have shown that the MAPK3/1 signalling pathway is associated with events which contribute to the regulation of STAR expression and steroidogenesis in granulosa and Leydig cells (Johnson \& Bridgham 2001, Martinelle et al. 2004, Tosca et al. 2005, 2006). The decrease in IGF1-induced MAPK3/1 phosphorylation in 
response to NAMPT may thus help explain the reduction in progesterone production by hen granulosa cells. We did not investigate the effect of rhVisf on IGF1 receptor activation in the present study. The identity of the NAMPT receptor is still unknown; however, we can speculate that rhVisf binds to IGF1R and decreases IGF1 receptor tyrosine phosphorylation and that this accounts for the inhibition of IGF1-induced MAPK3/1 phosphorylation and progesterone production. In mammals, NAMPT modulates INSR signalling pathways, including tyrosine phosphorylation of the INSR $\beta$ subunit and its substrates, insulin receptor substrate 1 (IRS1) and IRS2, in human osteoblasts (Xie et al. 2007). Other adipokines, such as resistin and chemerin, have also been shown to reduce IGF1R signalling in human granulosa cells (Reverchon et al. 2012, 2013b).

\section{Concluding remarks}

In summary, NAMPT is expressed in hen ovarian follicles and, more specifically, in granulosa and theca cells of hierarchical follicles. In hens, plasma NAMPT levels are significantly lower in adults than they are in young birds. In vitro recombinant human NAMPT decreases basal and IGF1-induced production of progesterone by primary hen granulosa cells. This effect is associated with a reduction in STAR and HSD3B protein levels and MAPK3/1 phosphorylation. Taken together, these data suggest that NAMPT plays a role in hen folliculogenesis and, more precisely, in the control of steroidogenesis.

\section{Supplementary data}

This is linked to the online version of the paper at http://dx.doi. org/10.1530/REP-15-0021.

\section{Declaration of interest}

The authors declare that there is no conflict of interest that could be perceived as prejudicing the impartiality of the research reported.

\section{Funding}

This work was financially supported by an 'Adipofertikines' grant (grant number 32000407) from Région Centre.

\section{Acknowledgements}

The authors wish to thank all of the animal staff for providing the animals used in this study.

\section{References}

Akiba Y, Chida Y, Takahashi T, Ohtomo Y, Sato K \& Takahashi K 1999 Persistent hypoglycemia induced by continuous insulin infusion in broiler chickens. British Poultry Science 40 701-705. (doi:10.1080/ 00071669987124)

Brandauer J, Vienberg SG, Andersen MA, Ringholm S, Risis S, Larsen PS, Kristensen JM, Frosig C, Leick L, Fentz J et al. 2013 AMP-activated protein kinase regulates nicotinamide phosphoribosyl transferase expression in skeletal muscle. Journal of Physiology 591 5207-5220. (doi:10.1113/jphysiol.2013.259515)

Braun EJ \& Sweazea KL 2008 Glucose regulation in birds. Comparative Biochemistry and Physiology. Part B, Biochemistry \& Molecular Biology 151 1-9. (doi:10.1016/j.cbpb.2008.05.007)

Canepa S, Laine AB, Bluteau A, Fagu C, Flon C \& Monniaux D 2008 Validation d'une methode immunoenzymatique pour le dosage de la progesterone dans le plasma des ovins et des bovins. Les Cahiers Techniques de L'INRA 64 19-30.

Chabrolle C, Tosca L, Crochet S, Tesseraud S \& Dupont J 2007a Expression of adiponectin and its receptors (AdipoR1 and AdipoR2) in chicken ovary: potential role in ovarian steroidogenesis. Domestic Animal Endocrinology 33 480-487. (doi:10.1016/j.domaniend.2006. 08.002)

Chabrolle C, Tosca L \& Dupont J 2007b Regulation of adiponectin and its receptors in rat ovary by human chorionic gonadotrophin treatment and potential involvement of adiponectin in granulosa cell steroidogenesis. Reproduction 133 719-731. (doi:10.1530/REP-06-0244)

Chabrolle C, Tosca L, Rame C, Lecomte P, Royere D \& Dupont J 2009 Adiponectin increases insulin-like growth factor I-induced progesterone and estradiol secretion in human granulosa cells. Fertility and Sterility 92 1988-1996. (doi:10.1016/j.fertnstert.2008.09.008)

Cheng Q, Dong W, Qian L, Wu J \& Peng Y 2011 Visfatin inhibits apoptosis of pancreatic $\beta$-cell line, MIN6, via the mitogen-activated protein kinase/phosphoinositide 3-kinase pathway. Journal of Molecular Endocrinology 47 13-21. (doi:10.1530/JME-10-0106)

Choi KH, Joo BS, Sun ST, Park MJ, Son JB, Joo JK \& Lee KS 2012 Administration of visfatin during superovulation improves developmental competency of oocytes and fertility potential in aged female mice. Fertility and Sterility 97 1234-1241. (doi:10.1016/j.fertnstert.2012.02.032)

Coyral-Castel S, Rame C, Fatet A \& Dupont J 2010 Effects of unsaturated fatty acids on progesterone secretion and selected protein kinases in goat granulosa cells. Domestic Animal Endocrinology 38 272-283. (doi:10. 1016/j.domaniend.2009.12.002)

Dahl TB, Yndestad A, Skjelland M, Oie E, Dahl A, Michelsen A, Damas JK, Tunheim SH, Ueland T, Smith C et al. 2007 Increased expression of visfatin in macrophages of human unstable carotid and coronary atherosclerosis: possible role in inflammation and plaque destabilization. Circulation 115 972-980. (doi:10.1161/CIRCULATIONAHA.106.665893)

Dupont J, Dagou C, Derouet M, Simon J \& Taouis M 2004 Early steps of insulin receptor signaling in chicken and rat: apparent refractoriness in chicken muscle. Domestic Animal Endocrinology 26 127-142. (doi:10. 1016/j.domaniend.2003.09.004)

Gurusubramanian G \& Roy VK 2014 Expression of visfatin in alloxaninduced diabetic rat testis. Acta Histochemica 116 1462-1468. (doi:10. 1016/j.acthis.2014.09.011)

Hameed W, Yousaf I, Latif R \& Aslam M 2012 Effect of visfatin on testicular steroidogenesis in purified Leydig cells. Journal of Ayub Medical College, Abbottabad: JAMC 24 62-64.

Imai S 2009 Nicotinamide phosphoribosyltransferase (Nampt): a link between NAD biology, metabolism, and diseases. Current Pharmaceutical Design 15 20-28. (doi:10.2174/138161209787185814)

Johnson AL \& Bridgham JT 2001 Regulation of steroidogenic acute regulatory protein and luteinizing hormone receptor messenger ribonucleic acid in hen granulosa cells. Endocrinology 142 3116-3124.

Khan JA, Tao X \& Tong L 2006 Molecular basis for the inhibition of human NMPRTase, a novel target for anticancer agents. Nature Structural \& Molecular Biology 13 582-588. (doi:10.1038/nsmb1105)

Krzysik-Walker SM, Ocón-Grove OM, Maddineni SR, Hendricks GL III \& Ramachandran R 2008 Is visfatin an adipokine or myokine? Evidence for greater visfatin expression in skeletal muscle than visceral fat in chickens Endocrinology 149 1543-1550. (doi:10.1210/en.2007-1301) 
Li J, Meng F, Song C, Wang Y \& Leung FC 2012 Characterization of chicken visfatin gene: cDNA cloning, tissue distribution, and promoter analysis. Poultry Science 91 2885-2894. (doi:10.3382/ps.2012-02315)

Martinelle N, Holst M, Soder O \& Svechnikov K 2004 Extracellular signalregulated kinases are involved in the acute activation of steroidogenesis in immature rat Leydig cells by human chorionic gonadotropin. Endocrinology 145 4629-4634. (doi:10.1210/en.2004-0496)

Morita Y, Wada-Hiraike O, Yano T, Shirane A, Hirano M, Hiraike H, Koyama S, Oishi H, Yoshino O, Miyamoto Y et al. 2012 Resveratrol promotes expression of SIRT1 and StAR in rat ovarian granulosa cells: an implicative role of SIRT1 in the ovary. Reproductive Biology and Endocrinology 10 14. (doi:10.1186/1477-7827-10-14)

Ocón-Grove OM, Krzysik-Walker SM, Maddineni SR, Hendricks GL III \& Ramachandran R 2010 NAMPT (visfatin) in the chicken testis: influence of sexual maturation on cellular localization, plasma levels and gene and protein expression. Reproduction 139 217-226.

Ons E, Gertler A, Buyse J, Lebihan-Duval E, Bordas A, Goddeeris B \& Dridi S 2010 Visfatin gene expression in chickens is sex and tissue dependent. Domestic Animal Endocrinology 38 63-74. (doi:10.1016/ j.domaniend.2009.08.007)

Park MJ, Park SH, Lee SK, Moon SE, Moon HS \& Joo BS 2011 Expression of SDF- $1 \alpha$ and leptin, and their effect on expression of angiogenic factors in mouse ovaries. Clinical and Experimental Reproductive Medicine 38 135-141. (doi:10.5653/cerm.2011.38.3.135)

Reverchon M, Cornuau M, Rame C, Guerif F, Royere D \& Dupont J 2012 Chemerin inhibits IGF-1-induced progesterone and estradiol secretion in human granulosa cells. Human Reproduction 27 1790-1800. (doi:10.1093/humrep/des089)

Reverchon M, Cornuau M, Cloix L, Rame C, Guerif F, Royere D \& Dupont J 2013a Visfatin is expressed in human granulosa cells: regulation by metformin through AMPK/SIRT1 pathways and its role in steroidogenesis. Molecular Human Reproduction 19 313-326. (doi:10.1093/molehr/ gat002)

Reverchon M, Cornuau M, Rame C, Guerif F, Royere D \& Dupont J 2013 b Resistin decreases insulin-like growth factor I-induced steroid production and insulin-like growth factor I receptor signaling in human granulosa cells. Fertility and Sterility 100 247-255. (doi:10.1016/j.fertnstert.2013. 03.008)

Reverchon M, Rame C, Bertoldo M \& Dupont J 2014 Adipokines and the female reproductive tract. International Journal of Endocrinology 2014 232454. (doi:10.1155/2014/232454)

Revollo JR, Grimm AA \& Imai S 2004 The NAD biosynthesis pathway mediated by nicotinamide phosphoribosyltransferase regulates Sir2 activity in mammalian cells. Journal of Biological Chemistry 279 50754-50763. (doi:10.1074/jbc.M408388200)

Revollo JR, Grimm AA \& Imai S 2007a The regulation of nicotinamide adenine dinucleotide biosynthesis by Nampt/PBEF/visfatin in mammals. Current Opinion in Gastroenterology 23 164-170. (doi:10.1097/MOG. Ob013e32801b3c8f)

Revollo JR, Korner A, Mills KF, Satoh A, Wang T, Garten A, Dasgupta B, Sasaki Y, Wolberger C, Townsend RR et al. 2007 b Nampt/PBEF/Visfatin regulates insulin secretion in $\beta$ cells as a systemic NAD biosynthetic enzyme. Cell Metabolism 6 363-375. (doi:10.1016/j.cmet.2007.09.003)

Rongvaux A, Shea RJ, Mulks MH, Gigot D, Urbain J, Leo O \& Andris F 2002 Pre-B-cell colony-enhancing factor, whose expression is up-regulated in activated lymphocytes, is a nicotinamide phosphoribosyltransferase, a cytosolic enzyme involved in NAD biosynthesis. European Journal of Immunology 32 3225-3234. (doi:10.1002/1521-4141(200211)32:11< 3225::AID-IMMU3225>3.0.CO;2-L)

Sauveur B \& de Reviers M 1988 Reproduction des volailles et production d'oeufs. Institut national de la Recherche agronomique. pp 1-449 Editor: INRA, Paris 1988.

Shen CJ, Tsai EM, Lee JN, Chen YL, Lee CH \& Chan TF 2010 The concentrations of visfatin in the follicular fluids of women undergoing controlled ovarian stimulation are correlated to the number of oocytes retrieved. Fertility and Sterility 93 1844-1850. (doi:10.1016/j.fertnstert.2008.12.090)

Simon J 1989 Chicken as a useful species for the comprehension of insulin action. Critical Reviews in Poultry Biology 2 121-148.

Song SY, Jung EC, Bae CH, Choi YS \& Kim YD 2014 Visfatin induces MUC8 and MUC5B expression via p38 MAPK/ROS/NF- $\mathrm{B}$ in human airway epithelial cells. Journal of Biomedical Science 21 49. (doi:10.1186/ 1423-0127-21-49)

Stocco DM 2001 StAR protein and the regulation of steroid hormone biosynthesis. Annual Review of Physiology 63 193-213. (doi:10.1146/ annurev.physiol.63.1.193)

Thomas S, Kratzsch D, Schaab M, Scholz M, Grunewald S, Thiery J, Paasch U \& Kratzsch J 2013 Seminal plasma adipokine levels are correlated with functional characteristics of spermatozoa. Fertility and Sterility 99 1256-1263. (doi:10.1016/j.fertnstert.2012.12.022)

Tosca L, Froment P, Solnais P, Ferre P, Foufelle F \& Dupont J 2005 Adenosine $5^{\prime}$-monophosphate-activated protein kinase regulates progesterone secretion in rat granulosa cells. Endocrinology $\mathbf{1 4 6}$ 4500-4513. (doi:10.1210/en.2005-0301)

Tosca L, Crochet S, Ferre P, Foufelle F, Tesseraud S \& Dupont J 2006 AMP-activated protein kinase activation modulates progesterone secretion in granulosa cells from hen preovulatory follicles. Journal of Endocrinology 190 85-97. (doi:10.1677/joe.1.06828)

Tosca L, Chabrolle C, Uzbekova S \& Dupont J 2007 Effects of metformin on bovine granulosa cells steroidogenesis: possible involvement of adenosine $5^{\prime}$ monophosphate-activated protein kinase (AMPK). Biology of Reproduction 76 368-378. (doi:10.1095/biolreprod.106. 055749)

Wu L, Zhang A, Sun Y, Zhu X, Fan W, Lu X, Yang Q \& Feng Y 2012 Sirt1 exerts anti-inflammatory effects and promotes steroidogenesis in Leydig cells. Fertility and Sterility 98 194-199. (doi:10.1016/j.fertnstert.2012. 04.008)

Xie H, Tang SY, Luo XH, Huang J, Cui RR, Yuan LQ, Zhou HD, Wu XP \& Liao EY 2007 Insulin-like effects of visfatin on human osteoblasts. Calcified Tissue International 80 201-210. (doi:10.1007/s00223-0060155-7)

Zhao Y, Liu XZ, Tian WW, Guan YF, Wang P \& Miao CY 2014 Extracellular visfatin has nicotinamide phosphoribosyltransferase enzymatic activity and is neuroprotective against ischemic injury. CNS Neuroscience \& Therapeutics 20 539-547. (doi:10.1111/cns.12273)

Received 13 January 2015

First decision 1 March 2015

Revised manuscript received 17 April 2015

Accepted 24 April 2015 